\title{
Fine-tuning the retail sector in India and the preconditions for FDI in Retailing
}

\author{
Anuradha. $\mathrm{A}^{1}$, Prabhu. $\mathrm{R}^{2}$

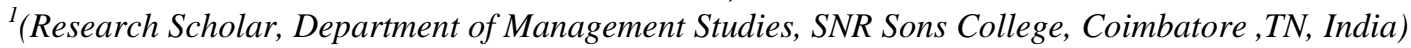 \\ ${ }^{2}$ (Professor, Department of Business Administration, Government College for Men, Krishnagiri, TN, India)
}

\begin{abstract}
Promoting organized retail in India was initiated by the Government of India in 2006 by opening up single brand retailing to FDI. The international players are allowed to enter into the Indian retail market through five entry routes Viz., franchising, joint venture, manufacturing, cash and carry wholesale trading and distribution. The value of the retail segment is expected to grow from an estimated INR 22.53 trn in 2012 to INR 27.73 trn by 2016.This paper seeks to discuss about the pros and Cons of "Wal-Mart effect" on the Indian economy by justifying the economic rationale for the need for FDI in retail sector. It also focuses on the externalities and the spillovers that would be experienced in the Indian market due to liberalization of FDI in retail sector and stresses upon certain preconditions that have to be recommended by the DIPP for the smooth functioning of the economy.
\end{abstract}

Keywords; Retailing, Externalities, FDI, Franchising, Comparative advantage,Bargaining power, Multi-brand.

\section{INTRODUCTION}

Foreign Direct Investment (FDI) plays a key role in economic development. Its role is manifold and can be analyzed under two different conditions: first, the determinants of FDI on development; second, causality between FDI and economic development. In the first case, the role of FDI is country specific and can be positive, negative or insignificant, depending on the economic, institutional and technological conditions in the recipient economy (Bhat et al., 2004; Kohpaiboon, 2006). The second case is, however, very diverging, particularly with reference to direction of causality. The divergence is due to time periods, country specifications and partly due to methodological differences. FDI has been widely recognized as a growthenhancing factor in the host country. It is not only a source of capital but also a medium for acquiring skills, technology, organizational and managerial practices and access to markets (Noorbakhsh et al., 2001). FDI introduces advanced technology and that can enhance the technological capability of the host country and hence, generating sustainable economic growth. Most interestingly, the technological benefit is not limited to locally affiliated firms but can also spread to non-affiliated ones. The latter benefit is usually called as technology spillover (Kugler, 2006; Moran, 2001). The process is however not automatic but depends upon country specific factors and policy environment. Moreover, the flows of FDI could be very positive, if there is integration of countries across the world. According to Feenstra and Markusen (1994), FDI determines growth through incorporation of inputs and technological absorption in the production process. In the first case, output growth can result from the use of a wider range of intermediate goods in FDI related manufacturing. In the second case, FDI is expected to be a potential source of productivity gains via spillovers effects.

\section{QUALITY VS QUANTITY OF FDI}

India began economic reforms in early 1990's; the economy has gradually opened up to the rest of the world with increasing FDI inflows and international trade. According to Summers (2000) "Social benefits" can be made by the efficiency gains from the reallocation of capital from industrial to developing countries. The reallocation can improve living standards by mobilizing global savings to finance investments in countries where the marginal productivity of investment is relatively high. Recently researchers recognized the fact that quality of FDI is more important than quantity alone. FDI is considered as higher-quality if it is export-oriented, transfers foreign technologies to the host country, and induces economic spillover benefiting local enterprises and workers (Ender wick 2005).

\section{CURRENT FDI POLICY IN RESPECT OF RETAIL SECTOR IN INDIA}

Currently, the foreign investor can make investments as per following guidelines:

1. FDI up to $100 \%$ for cash and carry wholesale trading and export trading allowed under the automatic route.

2. FDI up to $100 \%$ with prior Government approval for retail trade of 'Single Brand' products.

3. FDI up to $51 \%$ with prior Government approval for retail trade is permitted in Multi-Brand Retailing in India. 


\section{REASONS FOR WAL-MART'S INTEREST ON INDIAN MARKET}

- Lack of Competition: AT Kearney's study on global retailing trends found that India is least competitive as well as least saturated markets of the world. is only $20 \%$.

\section{THE HECKSCHER-OHLIN MODEL AND THE NEED FOR FDI (CAPITAL) IN INDIA}

Relative endowments of the factors of production (land, labor, and capital) determine a country's comparative advantage. Countries have comparative advantages in those goods for which the required factors of production are relatively abundant locally. This is because the profitability of goods is determined by input costs. Goods that require inputs that are locally abundant will be cheaper to produce than those goods that require inputs that are locally scarce.

For example, a country where capital and land are abundant but labor is scarce will have comparative advantage in goods that require lots of capital and land, but little labor - grains. If capital and land are abundant, their prices will be low. As they are the main factors used in the production of grain, the price of grain will also be low - and thus attractive for both local consumption and export. Labor intensive goods on the other hand will be very expensive to produce since labor is scarce and its price is high. Therefore, the country is better off importing those goods.

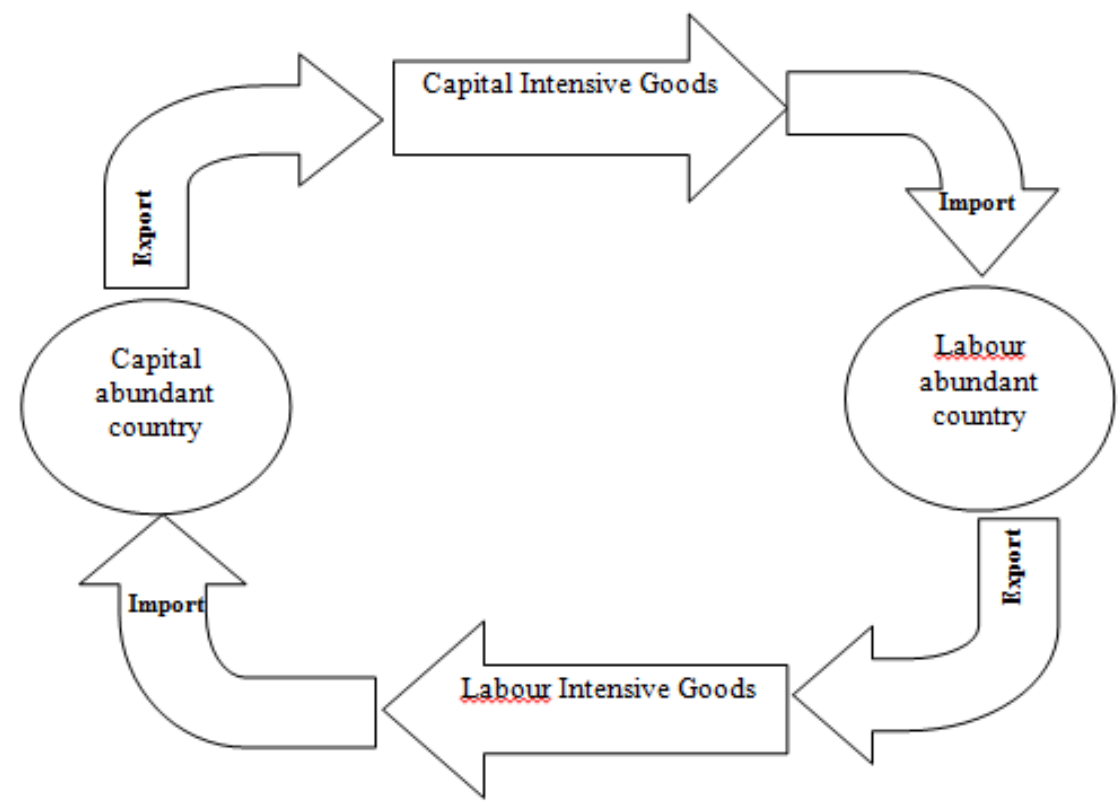

Fig 1.Pattern of International Trade under Heckscher-Ohlin (H-O) model

Ceteris Paribus, the above model holds good when the trade is bilateral. Today we are in the multilateral trading system and we do not have identical production technology and labour intensity among the countries of the world trading with each other. Therefore, though the countries of the world have realized the need to liberalize the trade regulations and help each other to reap the benefits of globalization it is the right time that our Indian Government has taken the initiative to attract the FDI in the retail sector. As only $2 \%$ of the retail sector is organized there is an urgent need to bring in a revolution in this sector by letting in the foreign retailers to do their business in India and to pen agreements to exchange technology and the knowhow. 


\section{DIAMOND MODEL AND THE RELEVANCE OF FDI IN RETAIL SECTOR IN INDIA}

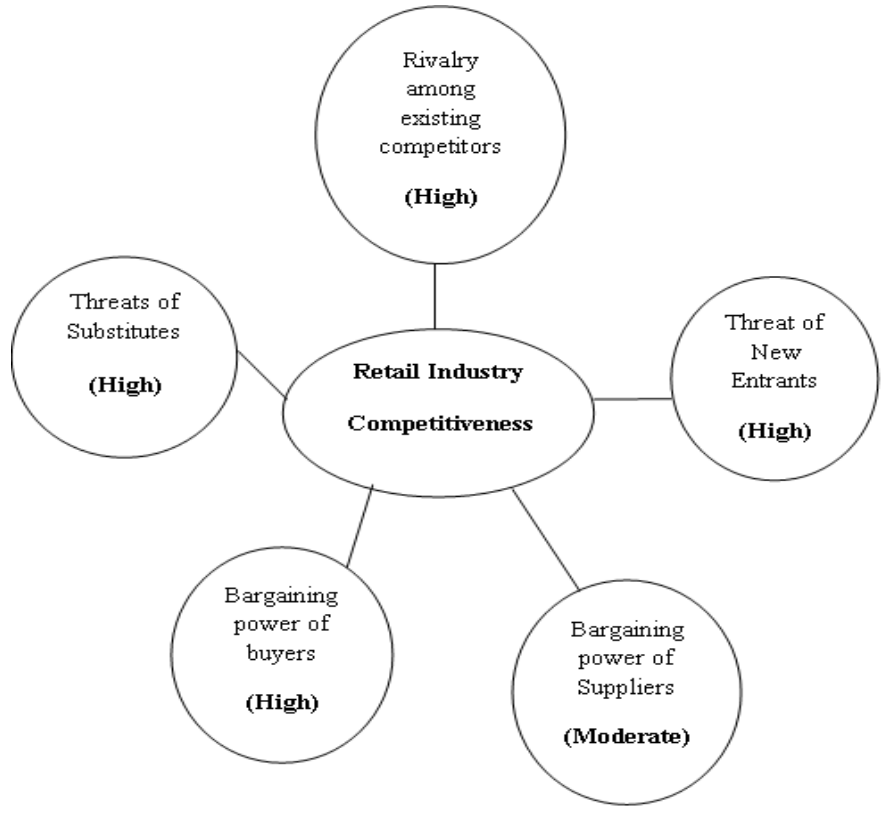

Fig 2. Porter's 5 Force Model

Average annual GDP growth of $7.7 \%$ is predicted for India by BMI through to 2016. With the population expected to increase from 1.26 bn in 2012 to 1.32 bn by 2016, GDP per capita is forecast to rise $77.9 \%$ by the end of the forecast period, reaching US \$2,980. The value of the retail segment is expected to grow from an estimated INR 22.53 trn in 2012 to INR 27.73 trn by 2016. With this economic condition it is necessary that we do a competitive analysis to find out the conducive environment for the infusion of FDI in retail sector and the consequences thereafter.

\section{Rivalry among existing competitors- High}

With the fine- tuning of the FDI in the multi-brand retailing there will be a stiff competition among the retailers within themselves and also with that of the existing unorganized retailers in India. Different kind of pricing strategies are practiced by the existing organized and unorganized retailers and the same will become more severe in the light of liberalization of FDI in multi-brand retailing paving the way for the rivalry among the existing competitors.

\section{Threat of New Entrants- High}

In India more than $97 \%$ of the retail market is made up of small and unorganized retailers. All the stores belonging to the small and unorganized sectors are not automated and do not even have computerized billing system. With the government's move to liberalize the retail sector up to $51 \%$ in multi-brand retailing in the phased manner there is much scope for the new entrants to strengthen the competition by way of offering additional benefits to the customers leading to a greater threat of new entrants in the existing market.

\section{Threats of Substitutes -High}

With the entry of Wal-Mart, Tesco, Carrefour and Metro into the market with $51 \%$ of FDI in multibrand retailing, organized stores will have the very common multiple-brands of the products and grocery items on their shelves and only their display merchandising strategies will differ. The private label brands will mushroom in a fast manner and this will lead to threats of substitutes among the organized as well as unorganized retailers existing in the retail sector in India.

\section{Bargaining power of buyers- High}

With the entry of the foreign retailers in the multi-brand retailing the customer who is the king will voice his commands to offer better quality of goods in a better quantity at a honest price as he always has the choice of a competitive corner shop to fill his grocery and other needs as India has the highest shopping density in the world with 11 shops per 1,000 people. 


\section{Bargaining power of Suppliers- Low}

FDI infusion in the multi-brand retail will definitely lead to a stiff competition and organized retailers will try to compete with each other to capture the market share and will also compete with the unorganized retailers. As the shopping density in India is high the bargaining power of the suppliers is low and the retailer should try to please his customers by all means through his offers and store attributes.

\section{THE PROSPECTED FDI BILL HAS THE FOLLOWING DRIVERS}

The retailers (both single-brand and multi-brand) will have to source at least 30\% of their goods from small and medium sized Indian suppliers.

All retail stores can open up their operations in cities having population over 1 million. Out of approximately 7935 cities and towns in India, 55 cities satisfy such criteria.

Multi-brand retailers must bring a minimum investment of US\$ 100 million. Out of this, half of the amount must be invested in back-end infrastructure facilities.

The opening of retail competition (policy) will be within the parameters of state laws and regulations.

VIII.

\section{COMPETITION COMMISSION OF INDIA}

CCI chairman Ashok Chawla has said that the entry of big players in the retail market would encourage competition. The commission is of the view that once the foreign retailers come, their functioning will be clear and then it can be seen that if at all there is a need for stringent regulation to step in. The commission also feels that there need not be over vigilance of multi-brand retail as it would be viewed like any other sector with no special dynamics. Experts too have viewed the move of liberalizing FDI in retail as a pro-reform process and something that would benefit all stakeholders - farmers, small manufacturers as well as customers as it has worked well for china's growth when china went for reform through FDI.

\section{ENTRY ROUTES TO FDI IN RETAIL SECTOR}

The international players are allowed to enter into the Indian retail market through five entry routes Viz., franchising, joint venture, manufacturing, cash and carry wholesale trading and distribution. Indian Government should encourage FDI through these routes to encourage employment in the economy.

\section{Franchising}

Franchising is one of the ways through which small retailers embrace organized retailing through brand association where there's a scope for leveraging business operations. With the entry of the foreign players the Franchising Association of India should encourage the small store owners to become a franchiser of the branded outlets in order to encourage modern format retailing with a healthy competition so that the customer is ultimately benefited.

\section{Joint venture}

A company believes that its reliance on business systems differentiates it from the competition and is a critical success factor for its growth strategy. FDI through Joint Ventures can help in transfer of technology and other technical knowhow paving a way for a unique business system. Most critical functions such as supply chain, operations, finance and accounts, customer relationship and human resources are now linked through a computer network. The corporate infrastructure and business systems are nowadays designed to handle large volumes, so the company hopes to reap more economies of scale as it moves to implement its expansion plans through joint ventures.

\section{Manufacturing}

The DIPP had also proposed riders like a minimum FDI of $\$ 100$ million (about Rs 450-460 crore), half of which would have to be invested in back-end infrastructure like cold storage, soil testing labs and seed farming. As there are concerns regarding credit flow, skill deficit and decline in manufacturing jobs, the Commerce and Industries ministry should formulate favourable norms for the infusion of FDI into the Indian economy to encourage manufacturing sector as well as to boost the jobs in this sector.

\section{Cash-and-Carry format}

Initially, India allowed FDI only in single brand retail chains like Nike and Louis Vuitton, with a cap of 51 per cent. Now it permits $100 \%$ overseas investment in wholesale cash-and-carry format stores. With the approval of 51\% stake in Multi-brand retail several big chains like Wal-Mart, Carrefour, Metro and Tesco have opened their wings for a full-scale entry into the multi-brand retail segment. 


\section{Distribution}

Distribution is the main function in retailing. If we go by the World Bank report, the price realization for the Indian Farmer is one of the lowest in the world i.e., 12 to $14 \%$. We produce about 230 million tones and our post harvest losses are 35 to $40 \%$. This is unacceptably high. This gap can be filled only by investing more on the rural infrastructure especially in the rural roads and transport facilities. The department of Commerce and Industries along with the Ministry of Rural Development have decided to invest Rs.40,000 Crores in the rural infrastructure. This along with the foreign investments in the retail sector will increase the employment opportunities as well as pave the way for better logistics cum reverse logistics facilities to the retailers.

\section{PROS AND CONS OF ALLOWING THE FDI IN RETAIL SECTOR}

The benefits of FDI investment in the retail sector

1. It improves the quality in the products and services because of higher competition

2. Will improve the lifestyle of the customers

3. Economies of scale would help lower consumer prices and increase the purchasing power of the consumer.

4. The invent of technology upgraded the system in terms of logistics, production and distribution channels. It adds as a driver in the Supply Chain Management.

5. The FDI will not only promote tourism and would develop skills and manpower.

\section{The demerits of FDI investment in the retail sector}

The arguments offered by critics against the retail sector reforms "Wal-Mart's effect" focus on the following points

- Independent stores will close, leading to massive job losses. Wal-Mart employs very few people in the United States. If allowed to expand in India as much as Wal-Mart has expanded in the United States, few thousand jobs may be created but millions will be lost.

- Wal-Mart or any other foreign retailer would lower prices to dump goods, get competition out of the way, become a monopoly, and then raise prices as we have already seen this in the case of the soft drink industry. Pepsi and Coke came in and wiped out all the domestic brands.

\section{PRECONDITIONS THAT HAVE TO BE RECOMMENDED BY THE DEPARTMENT OF INDUSTRIAL POLICY AND PROMOTION (DIPP) FOR THE SMOOTH FUNCTIONING OF THE ECONOMY}

India aims at increasing the share of manufacturing sector, which contributes over 80 per cent to the country's overall industrial production, from 16-17 per cent to 25-26 per cent of the gross domestic product by 2020. The government's concern is also over imposition of minimum alternative tax on special economic zones to encourage retail sector investments in the remote areas. The notification issued by the Department of Industrial Policy \& Promotion (DIPP) with regard to FDI in multi-brand retail is subject to certain conditions. Some of the main conditions cited are listed below

- Minimum amount to be brought in as investment by the foreign investor would be $\$ 100$ million. At least 50 per cent of this amount should be invested in 'back-end' infrastructure, which will include investments in processing, manufacturing, distribution, design improvement, warehouse, logistics, storage, etc. Investment in rentals and land cost will not be counted.

Little money will thus be available for the existing listed retailers to bring down their debts, which is a bigger worry for almost the companies. The government is sending a clear signal that the funds are to be deployed for asset creation.

- At least 30 per cent of the procurement of manufactured/processed products purchased shall be sourced from small industries with investment in plant and machinery not exceeding $\$ 1$ million. The investment limit will restrict purchases of smaller items. Electronics, garments, kitchenware, sports goods, consumer goods and most of the other items will not fall in this list. This would largely leave groceries and smaller gift items to be sourced from Indian players.

- Retail sales outlet may be set up in cities with a population greater than 10 lakh as per 2011 Census. The limit of a population of 10 lakh restricts the entry to around 37 cities in the country. But as the government has given the choice of implementing to the state government, the number falls down to around 19 cities in the country, with 10 cities being in Maharashtra alone. There will be a logistical issue for the players as they would require contiguous states in order to be operationally effective. 
- The policy is an enabling policy only and state governments would be free to take their own decision. The list of states that have agreed to multi-brand FDI are Andhra Pradesh, Assam, Delhi, Haryana, Jammu and Kashmir, Maharashtra, Manipur, Rajasthan, Uttarakand and the Union Territories of Daman \& Diu and Dadra and Nagar Haveli. Of the above list of states only five have cities which have a population of more than 10 lakh. The policy however, allows for setting up of retail shops in the largest city in case the state does not have a city with greater than 10 lakh population, purchasing power and other factors like security that would weigh in the mind of investors.

- Retail trading by means of e-commerce will not be permissible for companies with FDI.

This will be a dampener to companies like Amazon, which were looking at investing in the country.

\section{FDI POLICY ON MULTI BRAND RETAIL TRADING AND INDIA'S COMMITMENTS UNDER INTERNATIONAL INVESTMENT AGREEMENTS}

- Broadly two types of commitments are undertaken in an international investment agreement i.e. market access and national treatment.

- FDI policy is amenable to both market access and national treatment issues

1. Market access in the context of FDI policy implies the ability of a foreign investor to enter the investment space in India and the limitations thereon. For example, a foreign multi brand retail investor can invest in India only after the government decision is notified. Thus, access to the Indian market for multi brand retail is blocked for foreign investment till then.

2. National treatment implies that domestic and foreign investors are treated equally. The FDI policy itself envisages unequal treatment in a range of sectors which is embodied in the sectoral caps, security restrictions, etc. This means, for example, that while an Indian investor can invest $100 \%$ in multi brand retail trading in India, a foreign investor will still be allowed to invest only $51 \%$. Further, all the attendant conditions of the policy have only to be complied with by the foreign investor and not an Indian investor setting up a multi brand store without foreign investment

- BIPA: The Bilateral Investment Promotion \& Protection Agreement (BIPA) is a post-establishment investment agreement. This implies that once an investor enters the country, that investor must be treated the same as a domestic investor unless the limitations to national treatment are clearly spelt out at the pre-establishment stage. The FDI policy is a pre-establishment instrument and therefore not covered by BIPA.

- CECA/CEPA: Through the Comprehensive Economic Cooperation Agreement (CECA) and the Comprehensive Economic Partnership Agreement (CEPA) India has taken both pre and post establishment commitments. In the pre-establishment commitments, the FDI policy has been bound which means that any rollback would require consultations with the partner country and could entail quid pro quo in terms of concessions in some other area. Within the FDI policy, commitments may be taken only in some specified sectors (positive listing). Since FDI in multi brand retail trading was not allowed when these agreements were negotiated, none of these agreements is affected by the recently approved policy. Moreover, state and local regulations are not a part of the commitments.

- Multilateral/WTO: Multi brand retail trading is classified as a service and therefore covered by the General Agreement on Trade in Services (GATS). India has not undertaken any commitments in this area under the GATS. As such, there is no impact of the policy on our commitments under the WTO. Investment is not a part of WTO disciplines except through Mode 3 under GATS.

- The recently approved policy on FDI in multi brand retail trading provides, inter-alia, that it would be the prerogative of the states to allow a multi brand store. The policy nowhere provides that it is applicable only to certain states. The policy itself is a national policy and can potentially be applicable to all the states that are desirous of implementing it. The local and state-level regulations which govern shops and establishments are the prerogative of the respective state governments. The policy explicitly acknowledges this position. The opening up of FDI in multi brand retail trading is a liberalization measure and remains so with all the conditionalties, given the fact that currently FDI in multi brand retail trading is not allowed at all in India. The decision does not violate any commitments/obligations arising out of India's international agreements. 


\section{CONCLUSION}

To conclude, unlike in BPO industry, where the work will be done by Indians and profits will go to the foreigners FDI in Multi-brand retail should favour both the parties, the home country's economy as well as the foreign country's economy. As we are in the early days for multi-brand retail, it is unlikely that any investor would be in a hurry to declare their investment in the country till the dust settles down except for a very few major players like Wal-Mart and Carrefour. Tradeoffs involved in selective FDI approvals and foreign ownership restrictions should be done in a phased manner to achieve economic growth without affecting the small and medium shop owners in the country. The DIPP should be more concerned about the $30 \%$ of procurement of the foreign retailer from the home country and their investments in the supply chain infrastructure.

\section{REFERENCES}

[1]. Anu Antony (2009) “The Transitional Shift Of Indian Market Space and FDI In Retail”, GMJ, Vol. 3, 55-59.

[2]. Anand Dikshit (2011)," The Uneasy Compromise- Indian Retail”, The Wall Street Journal.

[3]. Bhatt, K. S., Tripura, S. C. U. and Raj, K. D. (2004). "Causal Nexus between Foreign Investment and Economic Growth in India", Indian Journal of Economics, 337, 171-185.

[4]. Kohpaiboon, A. (2006). "Foreign Direct Investment and Technology Spillover: A Cross-Industry. Analysis of Thai Manufacturing", World Development, 34, 541-556.

[5]. Ritesh Kumar Singh and Prerna Sharma (28 Sep, 2012) "Retail needs more than FDI", The Hindu. Business Line.

[6]. Penelope B. Prime, Vijaya Subrahmanyam and Chen Miao Linc (2012), "Competitiveness in India and China: the FDI puzzle", Asia Pacific Business Review, Vol. 18, No. 3, 303-333.

[7]. Rupali Gupta and Payal Malik (2011-12) FDI in Indian retail Sector: Analysis of competition in Agri-food sector, Internship Project Report.

[8]. Business India Intelligence (2005)” Shop till they drop “, Vol 12, No.18

[9]. Ranjan Kumar Dash and Chandan Sharma (2011), "FDI, Trade and foreign dynamics: New evidence from post reform India" The International Trade Journal", Volume 25, No. 2.

\section{Websites}

1. http://www.business-standard.com/india/news/analysis-decoding-fdi-in-retail/187872/on.

2. http://www.thehindubusinessline.com/industry-and-economy/article3974457.ece.

3. http://coresectorcommunique.blogspot.in/2012/09/fdi-policy-on-multi-brand-retail.html.

4. http://www.thehindubusinessline.com/opinion/article3946087.ece. 